\title{
Taxation in Romania during transition
}

\author{
Irina Bosie, “Alexandru Ioan Cuza”University of Iasi, România
}

\begin{abstract}
Taxation, as fundamental element of budgetary revenue, represents the subject of newest utilization. Budget revenues through importance they hold, exercises a direct influence on the behavior of people being used by natural and legal persons as modeling tools in the economic and social life. Using the generic concept of taxation we can obtain a plurality of components, it's defining elements, such as expression level of tax levies by various reports, the legal framework on tax revenue, financial institutions with responsibility for budgetary and fiscal powers, mandatory sampling methods, techniques and procedures used in the settlement and settlement revenue collection and budget. Performance of the economy at a time, effective use of public spending financed by taxes, public needs set by government policy and approved by Parliament, taxpayers, understanding of the budgetary needs, state of democracy in that country reached the level of taxation this one being determined by mentioned factors.
\end{abstract}

\section{Keywords:}

fiscality, transition, fiscal policy, reform

JEL Code: $H 25$

\section{Fiscal policies promoted in Romania during transition period.}

Legal framework for starting and creating tax reform in Romania was created with the adoption of legislation on the reorganization of state institutions as autonomous economic and commercial society. This was possible since 1990. Shortly thereafter, he was drafted and executed budget, stopped to centralize the state budget by payments of profits under a planned economy following de-budgeting economy. In turn, direct taxes were introduced as specific income tax, capital tax incomes, salary tax has been assigned the task owners income and business tax remains payroll, tax that exceeds the ceiling established by the government. A modern form of indirect tax called value added tax (VAT), appeared in 1993, the overall tax structure, replacing the tax on the movement of goods. This form of taxation was present in all other EU countries, and by adoption, Romania has made an important step in economic and financial restructuring. Duty taxes were used to adjust market supply and demand in times of economic life.

Also occurred, resulting in extra funds de-budgeting public spending. They were designed to cover certain obligations of the state.

\section{Taxation in Romania- European Union, the comparative analysis}

To refer to the tax systems of EU countries must present clear positioning Romania in the light of community landmarks, from requirements imposed by European countries for upgrading access to the single market, which has tough competition and operators characteristics of the member countries. 
Redistribution of gross domestic product and public financial resources coming from taxes and levies differ from each member country to another, depending on the degree of development of its economically. These operations aim to satisfy the general public interest. Under Revenue Statistics, countries in transition, aimed at EU accession have lower GDP than the EU countries with the most modest economic performance. They showed gross domestic product share of redistribution through taxes and contributions, close to the unweighted average of the EU. EU countries have manifested a tendency to increase the redistribution of GDP through taxes and contributions.

Shorter periods of time, comparable to those that are related to Romania in transition, retrospective analysis shows developments not only different from one country to another, but often contradictory. Thus, during 1985-1997, the share of tax revenue to gross domestic product, the total European Union increased by 1.7 percent. Of the 15 countries in 9 of them have been growing, and 6 reductions.

In Romania, between 1990-2001, was a loss of tax revenue to gross domestic product by 4.5 percentage points. It is important to indicate that the level of tax reduction has occurred as a result of reconsideration of tax policies promoted by the government and not as a result of declining production and gross domestic product collapse, as happened in Romania.

Taxation in Romania has made various developments, $\neg$ socio-economic conditions different from those of the European Union. In total tax revenue made throughout the European Union, participated in direct taxes accounted for over $50 \%$ and an indirect ratio below $50 \%$. Among the largest share of direct taxes their income taxes and income taxes. Indirect taxes have the largest share a tax on goods and services in all EU countries, direct taxes dominant feature.

For the rapid increase in indirect taxes has been made that argument would be that developed countries adopted a policy called the emphasis on financial resources.

But social and economic progress and prosperity in all European Union countries, has created functional common market, which favors the development of trade relations and determine need for common rules at Community level to promote free competition. Countries have different economic development levels favored by geographic location, with different fiscal policies, resulting in different financial features.

By assuming community acquis, Romania as member state is obliged to acquire, mandatory Community regulations. At the same time has a duty to develop and promote appropriate fiscal policy and conditions current stage of development interests.

Single currency and creation of the euro area determined to strengthen competitive capacity of the EU countries taken individually and taken together the Community. Euro currency movements $\neg$ advantage is that direct investment capital not to be influenced by monetary factors.

Tax reform is an integral part of economic reform in each state, with complex issues influenced by the political character of economic and social life, the process of training conducted over a long period of time and medium term fiscal reform for generating and maintaining money balanced development of economic structure in a uniform direction, measures for eliminating internal and external imbalances to achieve tax and social fairness and long-term tax revenue to the sizing and spending structure.

The goals of tax reform is tax reform measures to meet EU requirements: reducing the complexity of the tax system for taxpayers and tax administration device, attracting foreign investment, reducing the migration of capital and labor to countries with more taxes low economic imbalances caused by the removal of taxes on investment and business environment, improved balance of the tax system, by stimulating investment and employment (reducing unemployment).

\section{Tax reform effects}


Tax legislation must be clear and precise in interpretation and it is to determine the financial resources, encourage saving and long-term investment, increase transparency in fiscal policy, also increasing the progressivity of tax rates with favorable characteristics for low-income social levels, increase taxpayer confidence in the tax system, reducing the size of state sector institutions.

In the completion of tax reform measures are now willing to go to discourage tax evasion, remove tax exemptions from taxation, maintaining a low level of company profit tax rate and the maximum marginal rate of tax provided for staff so as to limit measures of income transfer between companies and personal income in two-way.

Minimum conditions for the proper administration of economic policy are tax reform and the need for a stable fiscal system professional tax preparation tax code according to the European Union, creating a modern information system and data sampling of tax, taxes and duties (e-tax e-administration, e-government).

Taxes are an economic policy instrument revealed by studying the effectiveness and efficiency of their taxes is the ability to provide the resources for major state objectives using both lower management costs. Taxes contribute to correcting the negative effects of the economy, and may be an intervention at both macro and micro level.

Tax structure must adhere to the goals of fiscal policy and economic policy. Economic, political and social influence and tax structure must meet the requirements of fiscal policy related to economic, budgetary, the phenomenon of inflation, social policy and that of investment.

\section{Instead of conclusions}

Among the solutions to resolve tax problems are situations that reflect an increase in taxes, and cases in which economic issues were resolved through tax cuts and tax rate development analysis shows a winding road. It is generally considered that any increase in the tax rate must be accompanied by important provisions for improving the equity of the tax system. Fairness it seeks to incorporate concepts that determine the balance and according to this principle are essentially equal in terms of revenue should pay equal taxes. Through fiscal policy, monetary and exchange with financial and economic instruments such as taxes, transfers and subsidies, credit, interest, prices, exchange rates, economic activity is influenced by public authority. Starting from a fair opportunity to avoid payment of taxes should be reduced as more and different sources of income need to be taxed.

Tax reform is required as a prerequisite for ensuring economic recovery of our country, aimed at aligning tax practices of developed countries and create a modern tax system. The tax system must meet the requirements of market economy by improving the taxation of personal income, re taxes, excise duty and local taxes. Romanian tax system puts undue pressure on social groups and stimulate investment in this area that do not require special skills, entrepreneurs uninvested in activities that require work to be remunerated properly qualified.

Thus fiscal policy requires a rapid restructuring in view of measures to increase transparency, provide a stable tax base, extensive tax reductions related to investment income, improved tax collection system, measures to reduce and prevent tax evasion and fraud and finally introducing the flat tax represents a plausible option for enhancement of European fiscal balance.

Taxes, assessment and tax contributions must act to support economic and population based on a real partnership between the state and taxpayers.

Government fiscal policy is designed to support the objectives of convergence with the budget deficit in the normal rate. The goal established by the Government is to deliver improved public services, including a system of quality education and training, a modern and reliable transport network and responsive health services. It ensures that these services be provided through increased public sector investment. 
In conclusion, we can say that the issue of taxes in the European Economic Area is not yet complete, due to differences in taxation both direct and indirect. Romania, as EU member, must meet regulations imposed by the Stability and Growth in multilateral coordination of economic and fiscal policies to develop programs as sustainable convergence.

\section{Bibliography}

1. Brezeanu P., Şimon I., Celea S., (2005), Fiscalitate Europeană, Ed. Economică, Bucureşti

2. Dăianu D., Vrânceanu R. (2002), România şi Uniunea Europeană, Ed. Polirom, Iaşi

3. Ştefura G. (2010), Procesul bugetar public, Ed. Universității Al. I. Cuza, Iaşi

4.Vintilă G.,Fiscalitate (2004), Metode şi tehnici fiscale, Ed. Economică, Bucureşti

5.***** Program de guvernare pe perioada 2005-2008 al Ministerului Finanțelor Publice;

6. ***** Raport de țară al Comisiei Europene pe anul 2006;

7. www.ccir.ro/ader - Sistemul fiscal în România; 